\title{
MLH1 Loss of Nuclear Expression
}

National Cancer Institute

\section{Source}

National Cancer Institute. MLH1 Loss of Nuclear Expression. NCI Thesaurus. Code C160413.

An indication that expression of MLH1 was not detected in the nuclei of cells in a sample. 